\title{
Limping as the first manifestation of malignant round cell tumor
}

\author{
Leila Mahboobi, Mehrnoush Hassas Yeghaneh*, Reza Shiari \\ From 21st European Pediatric Rheumatology (PReS) Congress \\ Belgrade, Serbia. 17-21 September 2014
}

\section{Introduction}

A 3.5 -year old boy was referred Out-patient Clinic of Pediatric Rheumatology in Mofid Children's Hospital because of limping. His problem was started 2 weeks before admission which accompanied by mid foot arthritis.

\section{Objectives}

This case is a report of midfoot arthritis that is a unusual manifestation of malignancy in children. there is not any special method for this abstract.

\section{Methods}

He was evaluated for the cause of limping that the results were as followings:

His Complete blood count showed normal levels of leukocyte without neutropenia, however, mild anemia (Hgb: $10.8 \mathrm{mg} / \mathrm{dl}$ ) and thrombocytosis (578000).

PPD test was negative. Acute phase reactants like ESR and CRP was elavated.

\section{Results}

Whole body bone scan revealed asymmetrical increased up take in ankle and linear increased up take in left metatarsus (3th).

His abdominal CT Scan showed multiple variable size hypodense lesions in bilateral kidneys and buldging and distortion of renal border.

Bone marrow biopsy performed that revealed positive for CD45 and CD3.

His renal lesions biopsy confirmed the diagnosis of Malignant Round Cell Tumor compatibale with T- Cell Leukemia and finally he went under the chemotherapy in oncology ward.

\footnotetext{
Pediatric Rheumatology, Shahid Beheshti University of Medical School,
} Tehran, Iran, Islamic Republic Of

(c) 2014 Mahboobi et al; licensee BioMed Central Ltd. This is an Open Access article distributed under the terms of the Creative Commons Attribution License (http://creativecommons.org/licenses/by/4.0), which permits unrestricted use, distribution, and reproduction in any medium, provided the original work is properly cited. The Creative Commons Public Domain Dedication waiver (http://creativecommons.org/publicdomain/zero/1.0/) applies to the data made available in this article, unless otherwise stated.

\section{Conclusion}

As the result of this article we conclude that midfoot arthritis is an alarming sign in children because of the assosiation with malignacies. So it is important to exclude malignacies in children whom presenting with only midfoot arthritis.

\section{Disclosure of interest}

None declared.

Published: 17 September 2014

doi:10.1186/1546-0096-12-S1-P281

Cite this article as: Mahboobi et al.: Limping as the first manifestation of malignant round cell tumor. Pediatric Rheumatology 2014

12(Suppl 1):P281.
Submit your next manuscript to BioMed Central and take full advantage of:

- Thorough peer review

- No space constraints or color figure charges

- Immediate publication on acceptance

- Inclusion in PubMed, CAS, Scopus and Google Scholar

- Research which is freely available for redistribution
- Convenient online submission

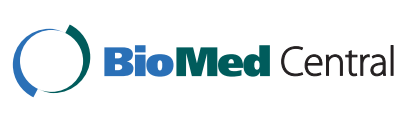

